\title{
Joan Littlewood's Post-Theatrical Engagements Beyond Theatre Workshop: A Comparison of the Original Fun Palace Project With the 2014 - 2015 Revivals*
}

\author{
Fatine Bahar Karlıdağ ${ }^{1}$ (D)
}

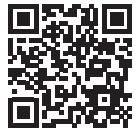

"This article is prepared with reference to the doctoral dissertation titled "Reading the Old Left in the Ewan MacColl and Joan Littlewood's Theatre Workshop and Beyond: in Joan Littlewood's post-theatrical engagements in the 1960s" which I completed in 2017 at the University of Washington, Seattle, School of Drama.

'Assist. Prof. Dr., Department of English Language and Literature, Yeditepe University, istanbul, Turkey

ORCID: F.B.K. 0000-0002-9253-6851

Corresponding author / Sorumlu yazar: Bahar Karlıdağ,

Department of English Language and Literature, Yeditepe University, İstanbul, Turkey

E-mail/E-posta: bahar.karlidag@yeditepe.edu.tr

Submitted/Başvuru: 30.03 .2021

Revision Requested/Revizyon Talebi:

21.04.2021

Last Revision Received/Son Revizyon:

06.05.2021

Accepted/Kabul: 08.06 .2021

\section{Citation/Atıf:}

Karlıdağ, Bahar. "Joan Littlewood's Post-Theatrical Engagements Beyond Theatre Workshop: A Comparison of the Original Fun Palace Project With the 2014 - 2015 Revivals" Tiyatro Eleștirmenliği ve Dramaturiji Bölümü Dergisi 32, (2021): 37-56

https://doi.org/10.26650/jtcd.906365

\section{ABSTRACT}

This paper suggests recognizing Joan Littlewood and Cedric Price's Fun Palace project as a blend of the Old Left and the New Left as it fulfills 1960s' faith in social progress through change in people's work/leisure balance on account of era's technological advances and also prioritizes Joan Littlewood's workingclass politics as it seeks to make urban centers accessible to all people's pastime activities. Fun Palace project was also introduced by Richard Schechner in The Drama Review issue of 1968 and therefore can be regarded in the whereabouts of early performance art definitions delineated by Schechner. Although Fun Palace resides in the dynamic New Left moment on the timeline, recognizing Littlewood's communistic commitments in Fun Palace idea is a necessary tribute to Joan Littlewood's life in working-class theatre, and a relevant perspective in probing the social and political potentials of the annual Fun Palace revivals initiated by Stella Duffy in 2014, the Joan Littlewood Centenary.

Keywords: Joan Littlewood, relational art, Fun Palace, Old Left, New Left 


\section{Introduction}

The implications of an artistic or cultural action as an opportunity for common/regular people outside the arts to try themselves at artistic practices, or 'artistic events,' can test canonical and formalizing restrictions on the arts; arts can be made communal, ensuing shared emotions, fresh and current symbolic meanings. Artistic actions are proposed by artists as relational actions to be shared in public spaces, looking for a rapport/interaction with witnesses/participants, seeking some co-presence to activate relational aesthetic potentials of an artwork. Nicolas Bourriaud defines relational aesthetics as "a set of artistic practices which take their theoretical and practical point of departure from the whole of human relations and their social context rather than an independent and private space." Such artistic actions have political implications; they are associated with social work that has potential to challenge public awareness. These definitions are applicable to the original idea of the Fun Palace project that was the brainchild of Joan Littlewood and Cedric Price in 1960s' London. The Fun Palace blueprint, which projected a vast, publicly accessible arts and crafts center in the visionary fervor of the New Left in 1960s England, lends itself to exploration in reference to Bourriaud's relational art as it emphasizes physical joint presence, creation and mobilization of communal sharing around art and also science work. The importance of the 1960s' moment in the Fun Palace theoretical frame is further stressed by the fact that Richard Schechner included the project in The Drama Review (Spring 1968 issue) titled "The Fun Palace," authored by Littlewood and Price, as he built a context towards defining environmental theatres of the 1968 revolutions. When one looks at the cover of the subject $T D R$, this context is starkly highlighted as a theme in large font: 'architecture/ environment. ${ }^{2}$ Emerging in the 1960s' new faith in social progress and possibilities of a new high-tech era, put in context with Schechner's earlier definitions of environmental theatre, and delineated by current scholarship in this precise context, Littlewood and Price's project seems fully submerged in the New Left fervor. Yet, I argue that it also resonates with the Old Left of the interwar period, with its emphasis on inclusivity, accessibility and visibility of the underprivileged in a central urban area, reminiscent of the historical working-class fights on being heard for their want of recognition, opportunities and jobs. During the Joan Littlewood centenary in 2014 and the following 2015, the Fun Palace idea re-emerged in the UK and went viral across the globe until the 2020 Covid-19 pandemic. The Fun Palace revivals have come close to the ideas that the original Fun Palace project instigated in terms of activating their local public in a relational sense as they shared artistic and cultural activities in their local 'Fun Palaces, however, as Jenny King, who had the chance to work with Littlewood, also implies, these venues as local Fun Palaces do not observe Littlewood's Old Left sentiments which were integral to the blueprint of the original Fun Palace.

1 Nicolas Bourriaud, Relational Aesthetics (Les presses du réel, 2002), 113.

2 See TDR's front cover, TDR 12/3 (1968) in the Michael Barker Collection of Joan Littlewood, Subseries E, box 3, folder 12, Harry Ransom Center, University of Texas at Austin. 
Joan Littlewood and Ewan MacColl, founders of the Theatre Workshop ensemble, were the radical left-wing theatre revolutionaries who embarked on the journey of taking theatre to the working-class population in England in the mid-1930s, during the high times of the Workers' Theatre Movement. They survived many difficult tests of being a communistic ensemble in England and when they settled in East London permanently, in 1953, MacColl left his active participation, protesting in his true-blue communist fervor, the group's decision to quit its formative motivation to reach out to the working class, and instead, to play to the critics' circle of London's commercial stages. In 1956, the ensemble came out with Brendan Behan's tragic parody of the Irish people's reduced circumstances, their uprising and oppression by England, The Hostage and drew immediate critical attention and acclaim. Today the Theatre Workshop is known as the ensemble that revolutionized the British theatre. Following various successful transfers from London's East End to the famous theatre row, the West End, Joan Littlewood produced another hit, in 1963, Oh What a Lovely War! a documentary piece which treated the Great War as an object of farce in Theatre Workshop's typical working-class antimilitarism. Gradually her theatrical activity waned as she found new outlets to materialize her vision, and the age was the revolutionary age of the New Left in England; the 1968 fervor, only more technological, more space-bound and even more bourgeois. Littlewood's Fun Palace project happens to be a virtual manifestation of her involvement with that new revolutionary fervor which, I argue, drew her in for her commitment to the possibilities of bettering the lives of the under-privileged by offering them accessible, communal spaces of artistic, cultural interactions, which in fact perfectly translated the spirit and the dynamics of the Theatre Workshop stage and its rapport with its working-class audiences.

Surveying the archive material of the original project of Littlewood and Price, I have found that the annual Fun Palace events held across the UK, in her birth week in early October starting from 2014, were quite in keeping with the ideas of community engagement in most of Littlewood's post-theatrical, space-oriented projects. However, the revivals signify a new dimension of community service that is arguably debatable because the original project of Littlewood and Price implied a rendering of urban centers accessible to the metropolitan wanderers and strangers of unspecific class backgrounds rather than nearby community populations that the revivals observe.

This paper engages with two ideas of artistic action that Littlewood's Fun Palace project may induce: the original idea created by Cedric Price and Joan Littlewood in the 1960s and the Fun Palace revival initiated by Stella Duffy in 2014. I argue that while the revivals Duffy organized were in keeping with the spirit of the original project, research on the resonance of the revivals with the blueprint of the Fun Palace reveals that the original Fun Palace, albeit its birth in the New Left period, also observed the Old Left aspects of class politics. Almost all leftwing theatrical programs which were able to evolve into the postwar era and eventually 
into the 1960 s were either inadvertently commercialized or joined the ranks of new theatrical categories such as community theatres or applied theatre practices, with some exceptions such as Littlewood's own theatre, the Theatre Workshop, their repertory remained intact in its antiestablishment, pro-working-class agenda. However, like all revolutionaries and visionaries, Littlewood lent herself to possibilities of the new revolutionary era of late 1960s, the New Left in England. On a closer survey, honoring Littlewood's communistic backgrounds, one will find that the community-oriented practices of the Fun Palace revivals are somewhat removed from Old Left purposes of the original Fun Palace idea.

Furthermore, archival research reveals that the Fun Palace project was also hailed by Richard Schechner and discussed in his periodical, The Drama Review (1968) within the context of environmental theatres of the New Left and was thus weaved into the genealogy of performance art. In his essay titled 'Six Axioms,' Schechner published his observations on the environmental theatre and seemingly associated the Fun Palace project with this concept.

In this paper I survey the 2014 and 2015 Fun Palace practices, along with how the original Fun Palace project has been interpreted in scholarship and the points of divergence/convergence of the original idea from/with these interpretations. ${ }^{3}$

\section{Cedric Price and Joan Littlewood's Fun Palace}

Fun Palace was a dream of Joan Littlewood that never materialized due to the lack of sponsorship. It was designed and programmed between 1961-63; its feasibility studies were completed in 1964. Legally and administrative-wise it was set up as a foundation and registered as a charitable trust in 1966. It was withdrawn from the originally intended Lea Valley site in 1966, due to neighborhood objections and had to move to Stratford but in its ideal life, it was intended as a travelling, portable site that belonged more to a metropolitan than a community setting. ${ }^{4}$ It is possible to think that the Fun Palace was a recourse to dreams that Littlewood could not work out on the stage; an extension of her revolutionary fervor that she found could not manifest through the theatre. Fun Palace was not a theatre. It can be deemed as Littlewood's vigilant directorial aims to set people free in an artistic, cultural, innovative, idealized space to create ripple effects of change in their identities, views of life.

I suggest reading The Fun Palace idea as a diluted move of communist thinking that gets itself preoccupied with urban centers instead of considering the suggested benefits for

3 Although, due to Covid-19 pandemic, current debates on relational art making inevitably include virtual dimension, too, the digital Fun Palace platforms which started in 2020 are beyond the scope of this paper which concentrates on case studies where metropolitan/community access, physical proximity and joint presence are held as main criteria derived from Nicolas Bourriaud's explanations.

4 See chronology section of the 'Non program A Laboratory of Fun by Joan Littlewood Head of Project Committee' in The Drama Review, 134, in The Michael Barker Collection, Subseries E, Joan Littlewood in print, Box 3, Folder 12. Harry Ransom Center, UT Austin. 
the underprivileged, in its need to stay temporary, as a "a short-term play thing in which all of [them] can realize the possibilities and delights that a $20^{\text {th }}$ Century city environment owes [them]" and "must last no longer than [they] need it," leaving targeted population undefined, yet indicating a short span of interest, hinting at the robustness of the under-privileged classes and their modest educational backgrounds as well as the allowances of a fast-paced urban life style for such amusement spaces. ${ }^{5}$ Yet, I argue that it contrasted with the spatially destructive tenets of 1968 as it offered an accommodating, free urban space, "with architects, designers, engineers, cyberneticians, cooks, topologists, toy-makers, flow masters, think clowns, [that] offers you the occasion to enjoy, 24 hours a day, space, light, movement, air, sun, water, in a new dimension"; it planned to mobilize "international, national and private organizations," to set up a trust for its administrative and financial burdens and left all direction in the hand of teachers, scientists and artists. ${ }^{6}$ The motive of animating its audience is a common workingclass theatre characteristic of the 1930s, for example in Bertolt Brecht's work, and also in MacColl's and Littlewood's discourse. The spirit of the Old Left as it found only the best fit for the working class, and serving them with only the best in terms of technology, culture, art is quite removed from the revolutionary spirit of 1968 that Hans Enzensberger claims to have sprung from the middle class, and to have advocated for anarchy in the urban space and a deconstruction of many technological, social and artistic norms (like traditional theatre), starkly contrasting, I would argue, the working-class motivation to reach for the amenities of better life standards. ${ }^{7}$ Arguably, this distinction will guide perspectives on the social and political efficacy of the Fun Palaces held annually since 2014.

\section{Reconsidering canonical definitions through Littlewood's vision of the Fun Palace project}

It seems true that the Fun Palace revivals have a political edge. Looking at the activities and the community engagement, one can see that the events brought the communities together, engendering relational artistic and cultural practices and spaces. In her Fun Palace and other site-related projects, Littlewood embraced dreams beyond her theatre stage to fathom the emancipation of people through leisure activities, rather than implying a working-class emancipation which she and MacColl had envisioned as the task of their theatre. Nevertheless, I argue that her motives in Fun Palace embraced both the Old Left structures of feeling and the progressive spirit of the New Left.

Richard Schechner includes the Fun Palace project in a 1968 issue of The Drama Review where he also discusses for the first time, the defining characteristics of 'environmental theatre'

\footnotetext{
Mel Gussow Collection Container 109.1, Littlewood, Joan 1964-94. Harry Ransom Center. Ibid.

Hans Magnus Enzensberger, "Constituents of a theory of the media," in Marris, Paul., and Thornham, Sue. Media Studies: A Reader, (New York: New York University Press, 2000), 73.
} 
in the protest culture of 1968 revolutions. Littlewood and Price wrote an essay titled 'The Fun Palace' which includes two pages' of pictures of the project, itemizing the contents of the site, an argument section, and Littlewood's 'Non-Program.' Argument section describes Fun Palace as an impermanent site to instigate leisure activities in tune with ever-changing demands of the age: "A short life toy of dimensions and organizations not limited by or to a particular site is one good way of trying, in physical terms, to catch with the mental dexterity and mobility exercised by all today." The following section by Littlewood, titled "Non-Program a Laboratory of Fun,' begins with her classical Old Left contexts of factory workers and miners: "Those who at present work in factories, mines and offices will quite soon be able to live as only a few people can: choosing their own congenial work, doing as little of it as they like, and filling their leisure with what delights them." "The differences between the Old Left and the New Left are quite stark and yet, the Fun Palace project seems to lend itself to both revolutionary milestones. I argue that the Fun Palace case suggests a continuity of Littlewood's intentions shaped by the Old Left's structures of feeling although it has been mainly discussed and theorized in reference to New Left environs and its spatially driven performance paradigms. General tendency in scholarship in Littlewood's later career is to see this as a phase when her politically charged theatre work was watered down or when she dismissed class politics, giving way to a "self-created function as jester." 10 Littlewood herself eschewed theatre and called it as 'obsolete' as politics, and expressed in an interview that "the printed word bit for the theatre [was] out of date," signaling her future, post-theatrical occupations. ${ }^{11}$ However, tracing the class struggle thought as what Raymond Williams calls a 'structure of feeling' is quite possible when we look at her Bubble City projects or the famous Fun Palace project. These projects may seem to the formalist eye like the end of Littlewood's theatre, but I argue that they inherently run on the same class-politics driven performance motive.

The Fun Palace project fulfills Schechner's explanations of environmental theatre, yet also resonates with Theatre Workshop's Old Left manifestos and initiatives in many aspects. Schechner's observations of the performative street interventions of 1968 coincide with the New Left, yet a clear divide is perceivable between the New Left trends and Littlewood's project. Original Fun Palace idea remains loyal to the Old Left tenets albeit its extreme reliance on technology, live communication and spatiality as newly defined norms of environmental theatre listed by Schechner: Littlewood's Fun Palace project would ideally be portable and accessible to a diverse population of Londoners (class specifics not elaborated) at major urban spaces in the city for a temporary period. It would be a state-of-the-art technology space

8 Littlewood and Price, 'The Fun Palace', TDR 12/3 (1968), 129, in the Michael Barker Collection of Joan Littlewood, Subseries E, box 3, folder 12, Harry Ransom Center, University of Texas at Austin 129.

9 Littlewood, 'Non-Program A Laboratory of Fun', The Drama Review, 130.

10 Robert Leach, Theatre Workshop Joan Littlewood and the Making of Modern British Theatre (Exeter: University of Exeter Press, 2010), 143.

11 Mel Gussow Collection- 109.1 Littlewood, Joan 1964-1994, Harry Ransom Center. 
abounding with various media outlets, space for creation, fun and curiosity, located at the heart of the city within instant reach of all types of public/private transport. With its vision of broad accessibility, high technology, city and commoners' intermingling at its central locations, the original project was resonant with the Old Left that wanted the best for the working class in terms of access to technology and amenities; aiming to animate and educate them like a director looking to animate the foyer:

ARRIVE AND LEAVE [sic.] by train, bus, monorail, hovercraft, car, tube or foot at any time YOU [sic.] want to - or just have a look at it as you pass. The information screen will show you what is happening, no need to look for an entrance - just walk in anywhere. No doors, foyers, queues or commissionaries: it's up to you how you use it. Look around - take a lift, a ramp, an escalator to wherever or whatever looks interesting.

CHOOSE [sic]what you want to do or watch someone else doing it. Learn how to handle tools, paint, babies, machinery or just listen to your favorite tune. Dance, talk or be lifted up to where you can see how other people make things work. Sit out over space with a drink and tune in to what's happening elsewhere in the city. try starting a riot or beginning a painting - or just lie back and stare at the sky.

WHAT TIME IS IT? [sic] Any time of day or night, winter or summer - it really doesn't matter. If it's too wet that roof will stop the rain but not the light. The artificial cloud will keep you cool or make rainbows for you. Your feet will be warm as you watch the stars - the atmosphere clear as you join the chorus. ${ }^{12}$

It is possible to historicize Schechner's environmental theatre axioms as an attempt to read theatre's response to the new civic movements of the late sixties. In his survey of the exemplary historical models of environmental theatre, Schechner gives little credit to the Workers' Theatre Movement of the 1920s and 1930s' agit-prop performances which more radically responded to their historical moments. Arguably, Littlewood's intentions were shaped by the Old Left's structures of feeling which were instructive, reforming, revolutionary, whereas Schechner mostly observes and describes his contemporary situation that is the New Left that Enzensberger describes as destructive and revolutionary. The New Left's actors were mostly middle class, such as anti-war youth, and the spaces were draft centers and campuses - except for the civil rights marches - and Schechner observes the political edge in their mobilizations, to instigate a new theatre, appropriating the streets as "public arenas, testing grounds, stages for morality plays". ${ }^{13}$ Schechner writes in his article, "everyday street life is marked by movement and the exchange of space; street demonstrations are a special form of street life which depend on the heightened application of the everyday regulations. The ever-increasing use of public space

12 Mimeo and Ms material on Fun Palace Project, Box 3, Folder 9, The Michael Barker Collection, Harry Ransom Center.

13 Richard Schechner, Environmental Theater: An Expanded New Edition Including 'Six Axioms for Environmental Theater,' (New York: Applause, 1994), 55. 
outdoors for rehearsed activities is having its impact on the indoor theatre". ${ }^{14}$ Littlewood's theatrical partner Ewan MacColl's Theatre of Action sprang from similar tensions in 1934, in the wake of the divide between Workers' Theatre Movement's emphasis on agit-prop (and later social realism) versus the need to explore the indoors theatre by the young theatre activists. The streets were the roaming ground of left-wing activists to reach out to the non-theatre-going, public with their dramatic propaganda. ${ }^{15}$ 1930s' agitation and propaganda on the streets, duly called agit-prop, originated from Soviet Russia and were instigated and shaped by the communist ideology, in contrast to the New Left's revolutionary environments that were shaped more by random civil disobedience and the newly politicized middle-class protests of the historical moment. Therefore, clearly, Schechner's definitions of social activism as performance excludes earlier similar social and theatrical responses to the historical moment such as the interwar period's agit-props overseen by the historical Workers' Theatre Movement (WTM) or the Blue Blouse troupes, which seem to fit in with Schechner's descriptions of environmental theatre. Early twentieth-century hunger marches in England happened before the communist party interventions yet they were organized by the labor organizations and they come close to the norms of the civil rights marches that Schechner lists among his examples, which can be categorized as political actions rather than cultural or artistic, but they testify to the fact that the street had been a mature environment for the representation of political strife much earlier than 1968. Schechner was observing the political strife in his time and space: at visible urban space and most importantly, they mostly echoed the progressive middle class, as the owner of that urban space, who differed greatly from the marching unprivileged thousands in the Hunger Marches of the early $20^{\text {th }}$ century in Britain. In comparison, Joan Littlewood's Fun Palace would have been a temporary intervention to validate visibility of the under-privileged and aimed at providing them with non-discriminate access to major urban districts. This arguably signifies a class-oriented approach to occupying places, deliberately expressed by Littlewood in the typically Marxist remedy for severe capitalist urban expansionism: "building a shortterm play thing in which all of us can realize the possibilities and delights that a $20^{\text {th }}$ Century city environment owes us". ${ }^{16}$

In a 1969 interview with Margaret Croyden, Littlewood describes the project as such:

You see I envision a place where one works with a lot of finesse, with a lot of grammar, selfdiscipline, or a very articulated piece of art, and the next minute you're doing jazz. And you go from one to the other, and you love the grammar of the language. And the next minute you're taking off with what the jazz players did in their time, and that is opened to everybody, to the genius of each child or each older person... Well, side by side with this campaign to

14 Ibid., 50.

15 For more information on Theatre Workshop, see Howard Goorney and Ewan MacColl, Agit-Prop to Theatre Workshop: Political Playscripts, 1930-50 (Manchester, UK; Dover, NH, USA: Manchester University Press, 1986) and Howard Goorney, Theatre Workshop Story (London: E. Methuen, 1981).

16 Littlewood interview, Mel Gussow Collection Container 109.1, Littlewood, Joan 1964-94. Harry Ransom Center. 
live, which is quite hard, one literally says to everybody, to about two hundred miners with their wives and kids, let's play games. They can as you know, give you a creative notion of their own life, or their own pain or their own laughter, maybe only once. But it's something like the therapy of clowning that everyone needs, not just us lucky ones who are mad enough to spend our lives trying to get other people to enjoy themselves... ${ }^{17}$

Reiterating her care for the miners' distressed families and their humane needs for leisure and fun, the above quote is a clear emphasis on Littlewood's working-class concerns that shape her post-theatrical projects. These environment-focused paradigms were famously formulated by Richard Schechner as he defined the new 'environmental theatres' of 1968 to be elaborated into one of the defining frames of what we now know today as the performance art. Schechner refined the concept in 1994 as "environmental performance," meaning "one in which all the elements or parts [sic] making up the performance are recognized as alive." 18 Schechner's original conception of the environmental theatre relied on six tenets that broadly implied the expansive potentials of theatre by formulating possible interventions in its conventional set of relations; its use of space for the performance and audience; expanding possibilities of performance space; variations in focus; multiple and independent appeals of production elements upon audience and the replacement of the text with the process of performance. Schechner's observations of the performative street interventions of 1968 coincide with the New Left, yet Littlewood's Fun Palace project resonates with the Old Left tenets albeit its extreme reliance on technology, live communication, mobility, and spatiality.

\section{Fun Palace Scholarship}

Before sharing the details of the Fun Palace revivals, surveying the recent scholarship on Littlewood's Fun Palace idea will help establish grounds for comparison. Robert Leach calls Fun Palace, "a kind of twentieth-century equivalent to the eighteenth-century pleasure gardens," in cooperation with Cedric Price, the architect famously known for his "space-age utopianism". ${ }^{19}$ Characterizing it by its informality and flexibility, Leach stresses the project to be Littlewood's conception of a "university of the streets," offering various recreational and creative activities. However, Leach's reference to an idea of forming 'strong community $\operatorname{link}[\mathrm{s}]$ ' through the project does not sound like the original proposal, as the site was proposed to be open to all people of all ranks and from all districts of London and elsewhere, hence making no specific reference to a matter of community. ${ }^{20}$ The original Fun Palace project had a vocation to make downtown temporarily accessible to various classes (unspecified) and groups of people, which is closer to the notion of the millennial occupy movements, suiting

17 Joan Littlewood and Margaret Croyden, "Joan Littlewood: Interviewed by MARGARET CROYDEN." The Transatlantic Review, no. 33/34 (1969): 56-65. Accessed April 30, 2021. http://www.jstor.org/stable/41512832

18 Schechner, Environmental Theatre, x.

19 Leach, Theatre Workshop, 201.

20 Ibid. 
the context of how David Harvey discusses possibilities of reversing capitalist hegemonic expansions in the urban space in his essay, 'From space to place and back again: reflections on the conditions of postmodernity,' discussing the need to create alternative urban spaces to counter hegemonic space invasions. ${ }^{21}$ Nevertheless, the recent revivals differ from the original project in this sense. The extent of the millennial projects' vocations for creating what look more like urban playgrounds that explicitly counterpose any occupy sentiments can be debated. Likewise, the 'Argument,' published in The Drama Review in 1968, states wider social and urban concerns than communal ones in its description of the project:

The city today works in a constipated way, in spite of its physical and architectural limitations. The legacy of redundant buildings and the resultant use of patterns acts as a straitjacket to total use and enjoyment ... A short-life toy of dimensions and organizations not limited by or to a particular site is one good way of trying ... to catch up with the mental dexterity and mobility exercised by all today. ${ }^{22}$

Joan Littlewood describes the site in her 'Non Program' which featured in The Drama Review as

not only accessible to those living and working in the immediate neighborhood, but also accessible as a regional and national amenity ... allow [ing] random time usage [which makes the idea of community bonding a less likely outcome] ... [with] varied communication routes ... of a metropolitan or regional network passing [sic] the site,

due to the fact that the varying metropolitan destinations chosen for the site would probably differ in terms of public's attention to the offerings of the site and the local routines of the district. $^{23}$

Nadine Holdsworth offers a deeper analysis of the Fun Palace, referring to its difference from its contemporary projects for its cultural inclusiveness, and pointing out that Littlewood saw it as a "twenty-four-hour long, large-scale community center," interprets its communal functions in reference to Nicolas Bourriaud's relational aesthetics theory which draws attention to the possibility of art work's creating a relational space in an alienated society. ${ }^{24}$ This emphasis on community-building through relational aesthetics counters Littlewood's own accounts of her projects, such as when she expressed the following conceptions of the project in a 1964 interview: "it's a delight place, a learn place, a toy for people. You're not meant to look at it. You're meant to be in it. But you mustn't be addicted. It's a microcosm of a city. A toy where a woman can behave like a harlot if she wants to. Not a do-good place, a do-bad place," which

21 David Harvey, "From Space to Place and Back Again: Reflections on the Conditions of Postmodernity", in Mapping the Futures: Local Cultures, Global Change, Ed. Jon Bird, (London: Routledge, 1993), 2-29.

22 Littlewood, 'Non-Program,' The Drama Review, 133.

23 Ibid.

24 Nadine Holdsworth, Joan Littlewood's Theatre (Cambridge: CUP, 2011), 211. 
potentially counters the implications of community-building, reproducing, on the contrary, the rowdy feeling of emancipation and communication that Littlewood sought in her stageaudience relationship, in the vein of the interviewer's note: "anti-theatre, anti-art, anti-apathy" .${ }^{25}$ Further, Holdsworth refers to Cedric Price's cooperative inspiration as a visionary architect and their proposing "a radical re-conceptualizing of cultural democracy and participative learning," and reads the Fun Palace as their "rethinking of the spaces" for such possibilities. ${ }^{26}$

\section{Fun Palace Revivals}

Other than being the 100th year of the Great War, 2014 was marked in the British theatrical environment as the Joan Littlewood Centenary. The events included a round-the-year run of Theatre Workshop's Oh What a Lovely War! by the Theatre Royal in Stratford, the company's home from 1952 to 1979 . The centenary celebrations hosted an idea by Stella Duffy, a theatre director, actor and a novelist, who proposed a different type of celebration for the centenary, earlier in 2013, and her call started a chain-reaction across the UK to initiate the opening of more than 150 Fun Palaces in Britain alone. Duffy's idea was also taken up by theatre people beyond the British borders who made spaces available for Fun Palaces in other countries such as the US, Canada, Iceland, Germany and Japan. These venues opened their spaces on the weekend of 4th and 5th October 2014, just before Littlewood's 100th birthday on 6 October.

Duffy's motto was, 'everyone an artist, everyone a scientist,' which accurately relates Littlewood's motives in making arts and culture alive and accessible in all citizens' lives. The BBC website's subtitle for the news claimed the annual event, "The UK's biggest ever celebration of creative participation." ${ }^{27}$ The venues had to comply with the founding principles of the never-materialized Fun Palace, which Littlewood and Price had described as "free, local, innovative, transformative and engaging". ${ }^{28}$ The venues were free to offer their menu of activities to their locals for the weekend. The Reviews Hub website shared Duffy's statement about Fun Palaces as "a huge shout for culture at the heart of our communities, working towards democratizing arts and science and making them accessible to the people," and her hope that the centenary would become an annual weekend event and inspire new generations of artists and audiences all over the world. ${ }^{29}$ Ironically, the Arts Council, whom Littlewood

25 Littlewood, in an interview, expressed that she aimed for a sense of communion in her productions, like in the pubs, and the interviewer noted: "anti-theatre, anti-art, anti-apathy" in her transcript of the interview titled in an unedited version, 'Joan Littlewood, Oct. 1, 1964.' In Mel Gussow Collection, 109.1 Littlewood, Joan 19641994, in Harry Ransom Center, UT Austin.

26 Holdsworth, Joan Littlewood's Theatre, 219.

27 "Everyone an artist. Everyone a scientist.". BBC Arts -Get Creative.2014, Accessed on: 3/17/2021https://www. bbc.co.uk/programmes/articles/1lrjhX6F0NHBvvRFzb007B8/everyone-an-artist-everyone-a-scientist

28 "News: Fun Palaces project marks Littlewood centenary," The Reviews Hub Blog, July 21, 2014, http://www. thepublicreviews.com/news-fun-palaces-project-marks-littlewood-centenary/ (broken link)

29 Jenny King, “A Tribute to Joan Littlewood,” Theatre Cloud Blog, published February 4, 2015, http://theatrecloud.com/news/a-tribute-to-joan-littlewood (broken link) 
had repeatedly approached and who had rejected Theatre Workshop productions for most of her career, funded the project. ${ }^{30}$

The Fun Palace project suggested by Duffy quickly gained popularity on social media, too, sharing the events of the centenary weekend with the nation, and eventually recruiting more venues for the following year's event and furthermore, making it annual: Fun Palaces were repeated annually until the pandemic since 2014 with the same principles, and in 2020, the project was taken to the digital platform as with all cultural activities across the globe.

For a closer view of the Fun Palace revival, we can look at 2014 and 2015 events as examples. The revivals happened annually in the first weekend of October until the pandemic. The first year's events were hosted by more than 150 venues in the UK, beyond Duffy's expectations. A variety of venues opened their doors on the weekend commemorating Joan Littlewood's $100^{\text {th }}$ birthday in 2014: the weekend of $4^{\text {th }}$ and $5^{\text {th }}$ of October, including churches, libraries, theatre houses, parks, swimming pools, museums, schools, bakeries and cocoa houses, art, and community centers. Next to institutional hosts such as Birmingham Arts Museum, London Metropolitan Archives and museums, two theatre companies opened the smallest venues for the event: Big Telly Theatre's Fun Palace was a small size caravan and Agent 160 Theatre built a tent in the Wales Millennium Center. The event was offered freely to its neighboring citizens, to engage them through the weekend with arts, science and crafts. From what I could gather on Facebook, I can list these activities as baking, composing music and writing lyrics, conducting scientific experiments, water sports and games, designing costumes and wearing them, drawing and painting, children's theatres, junk sculpture, story-telling, improvisational 'DIY Theatres' of random card picking and performing, sandwich-making competitions, baking, street-size board games, weaving, work-outs, playing with clowns, photography, shadow puppetry, relief printing, painting with professional artists, 3D printing, building camera obscura, ice cream making, decorating, model building (e.g., flying Fun Palaces), ukulele and tambourine playing, story painting, pop and folk singing, origami and knitting, dressing up as mermaids, swimming, kayaking, yoga, giant origami, Japanese storytelling, seniors' sharing memories, mask making, geometric crochet learning, belly dancing, language learning, stained glass works, making comics, adult face painting, and sharing international breakfasts. ${ }^{31}$

It is possible to refer to a personal account of a Fun Palace experience from 2014 in the comments sections to Michael Billington's review of the centenary on The Guardian on 6

30 For the Arts' Council's rejections to fund the Theatre Workshop productions until mid-fifties, see Goorney's and MacColl's books mentioned earlier. Stella Duffy, 'Celebrating Joan Littlewood: it's time to build her fun palaces' The Guardian Theatre Blog, published 18 September 2013, Accessed on 4/30/2021, https://www.theguardian.com/stage/theatreblog/2013/sep/18/theatre-joan-littlewood-culture-fun-palaces

31 Fun Palaces Facebook page, Detailed photographs of events can be reached at Facebook page of Fun Palaces. Various events listed above are descriptions of pages with links. Fun Palaces' Facebook page. Accessed on: 10 Oct 2015. Available at: https://www.facebook.com/FunPalaces/photos/ ms.c.eJxFzNERwCAIA9CNeqKGwP6LtcLFnl ;PhABwjxwbDMAetM3mxjRe8 ; uKWDLKTNm7P8scPk ;O3 v s L 4 Z c ; b F v 7 p 1 D Z t 0 P y t m 5 _ t _ r f M u r b T K q 7 y 73 v m u fefqee A E u Z R R. bps.a.555668887911886.1073741833.488480977964011/555668904578551/?type=3\&theater 
October 2014. This person shared their experience in Brockwell Lido, an outdoor swimming pool:

As she would have loved the legacy dreamt up this weekend by Stella Duffy and Shelley Silas of Littlewood's long hoped for Fun Palaces. All around the country. We had ours at Brockwell Lido. And the sun shone! the mermaids dipped and flipped. You could play dominoes on the poolside or get your blood pressure taken, learn more about dance and science, sign language or the ecosystem. Glide on the pool in kayaks or try your hand at the cycling machines.It all went off, if you'll forgive the word, swimmingly. Gloriously.

I think Joan would have loved it. And to tower it all off, a screening of Oh What a Lovely War, Richard Attenborough's directorial debut. It was great - but you know, I'm over 50 and I can remember the impact the stage show made on me, watching it standing in the sawdust at the back of the stalls as there was then at the Theatre Royal. It was bitter and playful and terribly, terribly moving. ${ }^{32}$

Another piece indicative of events scheduled for the 2014 Fun Palace weekend was from the website of Theatre Royal at Stratford East, Theatre Workshop's home from 1953 to 1979, inviting people to contribute to their project of building a 'little wood' for Joan, under the banner: 'Stratford East Fun Palace 'Petit Bois' (A 'Little Wood'for Joan) in The Courtyard, Old Town Hall, 29 Broadway, Stratford, London E15 on Sunday 5 October 2014, 2-5pm" The Theatre called out to the community and asked to bring in "a real tree/sapling in a pot - or a homemade tree (use your imagination - make a tree out of whatever you can recycle!)" to assemble a forest of 100 trees for the afternoon, "in a marquee in the middle of Stratford!" the list of activities included learning to make a pin-hole camera, seed-bomb with community gardeners, twisting a balloon-dog, blowing a didgeridoo, making a wish, doing a tango, having a sing, and lying back and listening to a fusion of Argentinian music and other rhythms. ${ }^{33}$

2015 October's Fun Palaces took place in Australia and New Zealand, too, adding to the international network of the annual event that had already covered countries like Japan and Germany. In North America, there appeared to be two physical venues for the 2015 event; one of them in New York, Queens, Qed's Fun Palace. The North American region's digital Fun Palace was a radio show in Toronto, Canada: The Fun Palace Radio Variety Show. The show held an exclusive online space for the Fun Palace project for 24 hours for "streaming local content and connecting with Fun Palaces across the world". ${ }^{34}$ The other physical venue

32 backscratch, 6 October 2014 (5:25) comment on Michael Billington, "Joan Littlewood: Oh what a legacy," The Guardian, published October 6, 2014. Accessed 3/17/2021, http://www.theguardian.com/stage/2014/oct/06/ joanlittlewood-oh-what-a-legacy-centenary

33 Theatre Royal Stratford East's Facebook page, "FUN PALACE - 'PETIT BOIS' (A 'LITTLE WOOD' FOR JOAN)” Theatre Royal Stratford East's Facebook page. Accessed on: 10 Oct 2015 https://www.facebook.com/ events/1542737622624626/.

34 “The Fun Palace Radio Variety Show," Fun Palaces. Accessed on: 10 Oct 2015 http:/funpalaces.co.uk/discover/ the-fun-palace-radio-variety-show- $2 /$. 
in Canada was Cathedral Village Arts Festival Fun Palace in Saskatchewan, joining in with "storytelling, science of color, hair braiding, artist cards, weaving, "frankentoys \& more!".35

The utopian vision of the Fun Palace was imagined in 1960s when it seemed that technology would soon free the working people from their workaday lives, and everyone - not just the educationally and financially fortunate - would have free time and energy to learn, to explore, to play, to engage and eventually creativity would no longer be the monopoly of the privileged elite, and that the process would eventually blur the work-play boundaries. The revivals' initiator, Duffy, also referred to these events as a form of political engagement: after the first event in 2014, she wrote for The Labour Arts Alliance, a blog promoted by England's Labour Party, that the Fun Palaces across the nation provided ground for public access to arts, crafts and sciences and they eventually would bring political awareness to public. Duffy stated in her piece that the Fun Palaces were a way of staying politically engaged in the political arenas controlled by the "predominantly white, male, middle class," living in "apathy and disaffection," promoting austerity policies. ${ }^{36}$ Duffy reported that the Fun Palace event in the 2014 October attracted more than 60,000 people in England who were mostly volunteers, "often on minimal funding [...] people who had never before created a community event, let alone one engaging with both arts and sciences". ${ }^{37}$

The centenary was received well and without reservations by the theatre circles. In its first year's wake, Elizabeth Schafer, British theatre scholar, wrote in an article for Times Higher Education that the attempt was about doing something to bring art and science together and eventually make a difference for a community, and that " $[t]$ his risk-taking, big, brave, countercultural and slightly insane project seems far more Littlewoodian than yet another production of Lovely War". ${ }^{38}$ In a press release, Teesside University reported that both the university and the historic Ormsby Hall, where the Theatre Workshop was located for eighteen months in 1946 and 1947, were official Fun Palaces. Teesside University invited a guest lecturer, Jean Newlove, the Theatre Workshop choreographer and MacColl's second wife, to give a talk on October 9, 2014, to celebrate the centenary. As an insider to the theatrical collaboration between Littlewood and MacColl, Newlove reiterated the Leftist vision of their work that, she argued, was so strong that "MI5 kept an eye on them". ${ }^{39}$ Theatre Cloud blog writes that Jenny King,

35 "Cathedral Village Art Festival Fun Palace," Fun Palaces. Available at: http://funpalaces.co.uk/discover/ cathedral-village-arts-festival-fun-palace/ Accessed on: 10 Oct 2015.

36 Stella Duffy, "The opportunity to create boosts wellbeing, social cohesion and public engagement," Labour Arts Alliance, published on October 15, 2014. Accessed on: 10 Oct 2015. http://www.labourartsalliance.org. uk/the_opportunity_to_create_boosts_wellbeing_social_cohesion_and_public_engagement (Broken link)

37 Ibid.

38 Liz Schafer, "Stage Whispers: Joan Littlewood," Times Higher Education, published August 21, 2014. Accessed on: 15 Oct 2015 https://www.timeshighereducation.com/features/culture/stage-whispers-joan-littlewood/2015209. article.

39 "Modern British theatre made in Middlesbrough," Teesside University News Centre, published September 22, 2014. Accessed on: 1 April 2021 http://www.tees.ac.uk/sections/news/pressreleases_story.cfm?story_ $\mathrm{id}=4760 \&$ this_issue_title $=$ September\%202014\&this_issue $=256$. 
a friend of Littlewood, who worked as her assistant from 1973 to 1976, created a 35-minute film, A Tribute to Joan Littlewood, added to the common appreciation of her work, stating that Littlewood had broadened the classic repertoire, discovered new writers, and assembled a genuine company of extraordinary performers to create a fresh theatrical style of playing. Yet she also added that Joan Littlewood had been deeply engaged with the present. "If Joan were alive now," King said, "for sure, the horrors of Gaza would be under hers and Gerry's [her partner and ensemble manager] scrutiny rather than any revival of Oh What A Lovely War". I argue that if she were alive now, she would probably be interested in the horrors of Gaza rather than the initiation of the Fun Palaces, too, for that same reason. King related Littlewood's ideas about reviving the theatre: "There is more stimulus in reality than in these endless discussions about art, all the schematic ideas for reviving theatre. They're not the answer. The answer is all around us." 40

\section{For children and youth - inclusivity as class politics}

Littlewood's Old Left attitude continued in her more spatially oriented interventions as she worked in her Bubble City projects and London Summer Fair projects of 1967. Her revolutionary spirit turned to saving poverty-ridden districts' children from the streets, emancipating the less privileged urban populations in benevolently regulated spaces. A press release titled 'Industry helps the Arts Bubble,' and a press statement form the Corporation of London titled 'City of London Festival Big Day for the Children in the City' mention Fun Palace Itinerant Trust's Mobile Fair Project that included "toys, games and entertainment structures and events such as a 50' windmill with bells and clastons, an inflatable world where everything inflates, a humanoid, a bubble environment, and a human kaleidoscope, you can shout at a wall and watch it change color according to your tone." ${ }^{41}$ A churchyard was spared to designers working with Littlewood to try their ideas, and major industrial corporations such as Dunlopillo, $3 \mathrm{M}$ Company, Pirelli Ltd and Honda donated material. The overall design belonged to one of the Archigram Group founders, architect Peter Cook. ${ }^{42}$

Input from industrial giants such as these corporations present a historical phase of industry and arts cooperation for making artistic actions possible for commoners, and Littlewood took her dreams in all possible directions, sports included: in a 1973 interview that Littlewood gave to the Sunday Times, where she was asked how football could become a spectacle, her answer was like a summary of how Littlewood and MacColl regarded theatre for their working-class audiences: "The day of a match should be a festival, a pageant of sporting and other happenings ... [with] a choice of alternative activity while the match is taking place ... It would be better

40 Jenny King, "A Tribute to Joan Littlewood," Theatre Cloud Blog, published February 4, 2015, http://theatrecloud.com/news/a-tribute-to-joan-littlewood (broken link)

41 Press Release for City of London Festival summer fair, 1968, The Michael Barker Collection, Series I, Subseries D, The Fun Palace Trust, Box 3, Folder 10. Harry Ransom Center.

42 The Michael Barker Collection, Series I, Subseries D, The Fun Palace Trust, Box 3, Folder 10. Harry Ransom Center. 
than hanging around the pubs and getting bored ... the [football] clubs (she cites West Ham particularly) are possessive and secretive ... It's what we're battling; exclusiveness," expressing her attempts to cooperate with the district clubs to no avail. ${ }^{43}$ Thus, as Littlewood shared her ideas on how to enliven football, which she compared to theatre in terms of its dependence on the public, she reiterated her unerring position to stand for inclusion, education (in the same interview, she also throws in the idea of discussing the game after the match so that "really fervent fans and youngsters" could be kept off the streets) and entertainment. This position of Littlewood is a clear extension of a commitment to include the underprivileged in the cultural, artistic and sports affairs of the city and the nation. Her use of an excerpt from a progressive architecture periodical, Archigram, as an epigram for her Bubble City project's leaflet attests to her Old Left orientations while keeping up with the norms of community engagement and service:

We are nearing the time when we can all realize our aspirations. It is too simple to see this merely as the amassing of objects, but they represent pretty accurately the directions outwards that our mental environment can reach: to the furthest imaginable limits. This is the crux of the matter: in the past, the indulgences of the mind and in intellect (as applied to artefacts) was the privilege of the rich. ${ }^{44}$

These examples can testify to the continuing structure of the Old Left feeling in Littlewood's commitment to inclusion of and bringing access to the people in all affairs of the society even as she was submerged into the 1960s' spirit of events and happenings. She was never formalistically concerned with the outcome of her work and this kept her operating tools and projects dynamic and adapting to the new conditions. Littlewood proposed to produce the civic action as she shifted from directing theatre to enticing people to get active, imaginative and animated at a customized urban space sanctioned by the City or local government and supported by corporations. Hans Enzensberger regarded the New Left with a certain skepticism due to its inherent sadism in enjoying the spectacle of destruction (he uses the German word schadenfreude that online Merriam-Webster translates as "enjoyment obtained from the troubles of others") of technological tools along with various other structures. This is another contrasting point with the Old Left of the 1930s' propagandist art as MacColl had, at various times, expressed the importance, like Brecht, to come as possibly close to the new versions of the mass media as possible and include it on their stage. The two periods' comprehension of revolutionary action, therefore, were quite different.

43 John Lovesey, 'What the game needs,' Sunday Times, January 7, 1973, The Michael Barker Collection of Joan Littlewood, Series I, Subseries D, Mimeo and ms. material on Fun Palace project, Box 3, Folder 9. Harry Ransom Center.

44 Archigram 8, Bubble City (Pamphlet), The Michael Barker Collection, Series I, Subseries E, Box 3, Folder 12, Harry Ransom Center. 


\section{Conclusion}

In this paper, I aimed at clarifying the intentionality behind the Fun Palace project of Littlewood and Price and my motive was to bring an emphasis to Littlewood's working-class politics that reverberated through her post-theatrical activities such as the Fun Palace and other space-related projects. The Fun Palace project was conversant with both the genealogies of performance art as it was cited in the historical moment when Schechner was initiating definitions of environmental theatre, and the Old Left structures of feeling in Littlewood's theatrical and post-theatrical practices. The Fun Palace revivals that have happened since the 2014-15 Littlewood Centenary do offer socio-political possibilities for bringing communities together around artistic and crafts-related activities. However, recognizing Littlewood's Old Left intentions in Fin Palace can better augment future research in their capacity to argue for these revivals' proximities to the blueprint of the Fun Palace project and to propose new avenues of inclusion and action through arts and culture.

Stella Duffy, as she was awarded an OBE (Member of the Order of the British Empire) in 2016, acknowledged that the award she was receiving was quite at odds with 'the communist Joan,' but she made a point of using most means for sustaining the Fun Palace revival projects. ${ }^{45}$ It is certainly a perspective, and the origins of the Fun Palace idea need not determine the revivals' fare. However, it is also worthwhile to ponder Jenny King's reminder that Joan Littlewood's attention, were she alive in 2014, would be on the distressed cultures and geographies such as Gaza in 2014, rather than resuscitating the theatre art. Therefore, placing Littlewood's motives in the Old Left may help formulate further questions on the political implications of such artistic actions of the Fun Palace scale, their motives, and ends, and may propose a necessary tribute to Joan Littlewood's life in working-class cause, and moreover offer a democratic perspective in our neoliberal times.

Peer-review: Externally peer-reviewed.

Conflict of Interest: The author has no conflict of interest to declare.

Grant Support: I was able to conduct research at the Harry Ransom Center at the University of Texas at Austin with the help of a Harry Ransom Center Dissertation Fellowship I was awarded in 2016.

Hakem Değerlendirmesi: Dış bağımsız.

Çıkar Çatışması: Yazar çıkar çatışması bildirmemiştir.

Finansal Destek: University of Texas at Austin'e bağlı olan Harry Ransom Center'daki araştırmamı Harry Ransom Center Doktora Tezi Bursu ile gerceklestirdim.

45 'Stella Duffy, co-director of Fun Palaces, awarded an OBE.' Fun Palaces website, dd 11/6/2016. Accessed March 14, 2021, URL: https://funpalaces.co.uk/stella-duffy-co-director-of-fun-palaces-awarded-an-obe/ 


\section{BIBLIOGRAPHY / KAYNAKÇA}

Billington, Michael. "Joan Littlewood: Oh what a Legacy." The Guardian. Accessed February 14, 2017. www.theguardian.com/stage/2014/oct/06/joan-littlewood-oh-what-a-legacycentenary.

Bourriaud, Nicolas. Relational Aesthetics. Les presses du reel, 2002.

Duffy, Stella. "The Opportunity to Create Boosts Wellbeing, Social Cohesion and Public Engagement." Labour Arts Alliance. Accessed October 10,2015. http://www.labourartsalliance.org.uk/the_opportunity_ to_create_boosts_wellbeing_social_cohesion_and_public_engagement (broken link).

Enzensberger, Hans Magnus. “Constituents of a Theory of the Media.” In Media Studies: A Reader, edited by Marris, Paul and Sue Thornham, 68-91. New York: New York University Press, 2000.

"Everyone an artist. Everyone a scientist.”. BBC Arts -Get Creative.2014, https://www.bbc.co.uk/programmes/ articles/11rjhX6F0NHBvvRFzb007B8/everyone-an-artist-everyone-a-scientist accessed on: 3/17/2021.

Fun Palaces. "Cathedral Village Art Festival Fun Palace." Accessed October 10, 2015. http://funpalaces.co.uk/discover/cathedral-village-arts-festival-fun-palace/.

"The Fun Palace Radio Variety show.". Accessed October 10, 2015.

http://funpalaces.co.uk/discover/the-fun-palace-radio-variety-show-2/ .

. 'Stella Duffy, co-director of Fun Palaces, awarded an OBE.' Accessed March 14, 2021, URL: https:// funpalaces.co.uk/stella-duffy-co-director-of-fun-palaces-awarded-an-obe/.

"Facebook Page of Fun Palaces." Accessed October 10, 2015. https://www.facebook.com/FunPalaces/photos ms.c.eJxFzNERwCAIA9CNeqKGwP6LtcLFnl ;PhABwjxwbDMAetM3mxjRe8 ; uKWDLKTNm7P8scPk ;O3 _ vsL4Zc $;$;bFv7p1DZt0Pytm5 _t $\sim$ rfMurbTKq7y73vmufefqeeAEuZjRV

bps.a.555668887911886.1073741833.488480977964011/555668904578551/?type=3\&theater.

Goorney, Howard. The Theatre Workshop Story. London: E. Methuen, 1981.

Goorney, Howard, and Ewan MacColl. Agit-Prop to Theatre Workshop: Political Playscripts, 1930-50. Manchester, UK; Dover, NH, USA: Manchester University Press, 1986.

Harvey, David. "From Space to Place and Back Again: Reflections on the Conditions of Postmodernity." in Mapping the Futures: Local Cultures, Global Change. Edited by Jon Bird. London: Routledge, 1993.

Holdsworth, Nadine. Joan Littlewood's Theatre. Cambridge: CUP, 2011.

"Illinois Campus Commemorates the Centenary of WWI with Events for the Entire Community." Illinois News Bureau. Accessed January 5, 2015. http://news.illinois.edu/news/14/0819WWI_MichaelRothberg_ MarcusKeller.html.

Jenny King, “A Tribute to Joan Littlewood," Theatre Cloud Blog., published February 4, 2015, http:// theatrecloud.com/news/a-tribute-to-joan-littlewood (broken link)

Leach, Robert. Theatre Workshop: Joan Littlewood and the Making of Modern British Theatre. Exeter: University of Exeter Press, 2006.

Littlewood, Joan, and MARGARET CROYDEN. "Joan Littlewood: Interviewed by MARGARET CROYDEN." The Transatlantic Review, no. 33/34 (1969): 56-65. Accessed April 30, 2021. http://www. jstor.org/stable/41512832.

Marowitz, Charles. "Joan Littlewood.” The Telegraph. Accessed January 5, 2015. http://www.telegraph. co.uk/news/obituaries/1408012/Joan-Littlewood.html.

Mel Gussow Collection. Harry Ransom Center. The University of Texas at Austin.

Michael Barker Collection of Joan Littlewood and the Theatre Workshop ca. 1937-1975. Harry Ransom Center. The University of Texas at Austin. 
"Modern British Theatre made in Middlesbrough." Teeside University News Centre. Accessed January 5, 2015 http://www.tees.ac.uk/sections/news/pressreleases_story.cfm?story_id=4760 \& this_issue_ title $=$ September $\% 202014 \&$ this_issue $=256$

“News: Fun Palaces project marks Littlewood centenary,” The Reviews Hub Blog. July 21, 2014, http://www. thepublicreviews.com/news-fun-palaces-project-marks-littlewood-centen a r y/ (broken link).

"Remembering Joan Littlewood.” National Theatre. Accessed October 13, 2015.http://www.nationaltheatre. org.uk/discover/platforms/remembering-joan-littlewood

Schafer, Liz. "Stage Whispers: Joan Littlewood." (August 21, 2014) The Times Higher Education. Accessed 5 Oct $2015 \mathrm{https} / / /$ www.timeshighereducation.com/features/culture/stage -whispersjoanlittlewood/2015209.article.

Schechner, Richard. "6 Axioms for Environmental Theatre." The Drama Review: TDR 12/3 (1968): 41-64. doi:10.2307/1144353. http://www.jstor.org/stable/1144353 Accessed: 30-08-2016.

Environmental Theater: An Expanded New Edition Including 'Six Axioms for Environmental Theater'. New York: Applause, 1994. 
